\title{
Geoelectric Exploration of the Purísima-Rumicruz District, Jujuy Province, Argentina
}

\author{
Luciano López, ${ }^{1,2}$ Horacio Echeveste, ${ }^{1,3}$ Mario Tessone, ${ }^{1,3}$ \\ Marta Alperín, ${ }^{4}$ and Ricardo Etcheverry ${ }^{1,2}$ \\ ${ }^{1}$ INREMI, Facultad de Ciencias Naturales y Museo, UNLP, Calle 64 Esquina 120, 1900 La Plata, Argentina \\ ${ }^{2}$ Consejo Nacional de Investigaciones Científicas y Técnicas, (CONICET), 1917 Buenos Aires, Argentina \\ ${ }^{3}$ Comisión de Investigaciones Científicas de Buenos Aires, (CICBA), 1900 La Plata, Argentina \\ ${ }^{4}$ Universidad Nacional de La Plata, (UNLP), 1900 La Plata, Argentina \\ Correspondence should be addressed to Luciano López, lopezluciano@hotmail.com
}

Received 29 March 2012; Revised 24 July 2012; Accepted 20 September 2012

Academic Editor: Michael S. Zhdanov

Copyright () 2012 Luciano López et al. This is an open access article distributed under the Creative Commons Attribution License, which permits unrestricted use, distribution, and reproduction in any medium, provided the original work is properly cited.

\begin{abstract}
Purísima-Rumicruz district consists of several polymetallic veins, rich in copper and lead. The veins have a breccia texture and are located in shear bands, with locally high concentrations of sulfides in a carbonatic gangue. The host rock of the veins consists of a black shale sequence with thin levels of fine sands, with a low degree of metamorphism, and corresponds to the Acoite formation (Lower Ordovician). The depositional environment was an open clastic platform where storm processes prevailed. An exploratory program using induced polarization and resistivity with the dipole-dipole method was carried out with the objective of establishing geoelectric anomalies in depth, which would permit the identification of exploratory targets. The group of veins was divided into three sectors: Purísima, El Brechón, and La Nueva. Low-resistivity values correspond to faulty zones, some of which are related to surface veins. The presence of diagenetic pyrite in the shales of Acoite formation considerably increases background chargeability (induced polarization) values. However, small chargeability anomalies associated to low-resistivity values represent exploratory targets for the Purísima-Rumicruz district.
\end{abstract}

\section{Introduction}

Purísima-Rumicruz is a polymetallic mining district, located on the southern section of Cerro Colorado de Cobre, some $20 \mathrm{~km}$ southeast of the town of Abra Pampa (Cochinoca department, Jujuy province, Argentina).

Small-scale copper exploitation took place from the 1940 's to the early 1970 's, with a variable production during that period; reserves totalled some $6,750 \mathrm{t}$ of mineral, with $5.5 \% \mathrm{Cu}$ content. From the mid-1980s to date, a more ambitious exploitation plan has been in order. The firm that currently holds the mining concession is Bolland S. A.

A geophysical exploratory survey based on geoelectricinduced polarization (or chargeability), and resistivity, was carried out with the purpose of identifying exploratory targets for drilling aiming to increase the district's reserves. This time-efficient methodological approach has been a cornerstone of mining exploration for decades [1-4]. The research objective of this study was to detect zones with high chargeability which are spatially linked to zones of low resistivity, a combination of characteristics that has been demonstrated to be indicative of metalliferous mineralizations associated with shear zone veins $[5,6]$.

\section{Geologic Setting}

The Purísima-Rumicruz district is located on the limit of the geologic provinces of Puna and Cordillera Oriental. Mineral deposits are typically veins and are contained in rocks of the Acoite formation [7], of Tremadocian-Arenigian age, composed of sands and shales, and deposited on a platform in which storms dominated and determined a progradational sequence, and it increases in grain and strata thickness upsection. Cretaceous units from the Salta Group (Pirgua subgroup and Lecho formation) (Figure 1) are on tectonic contact on top of this unit. The host rocks of 


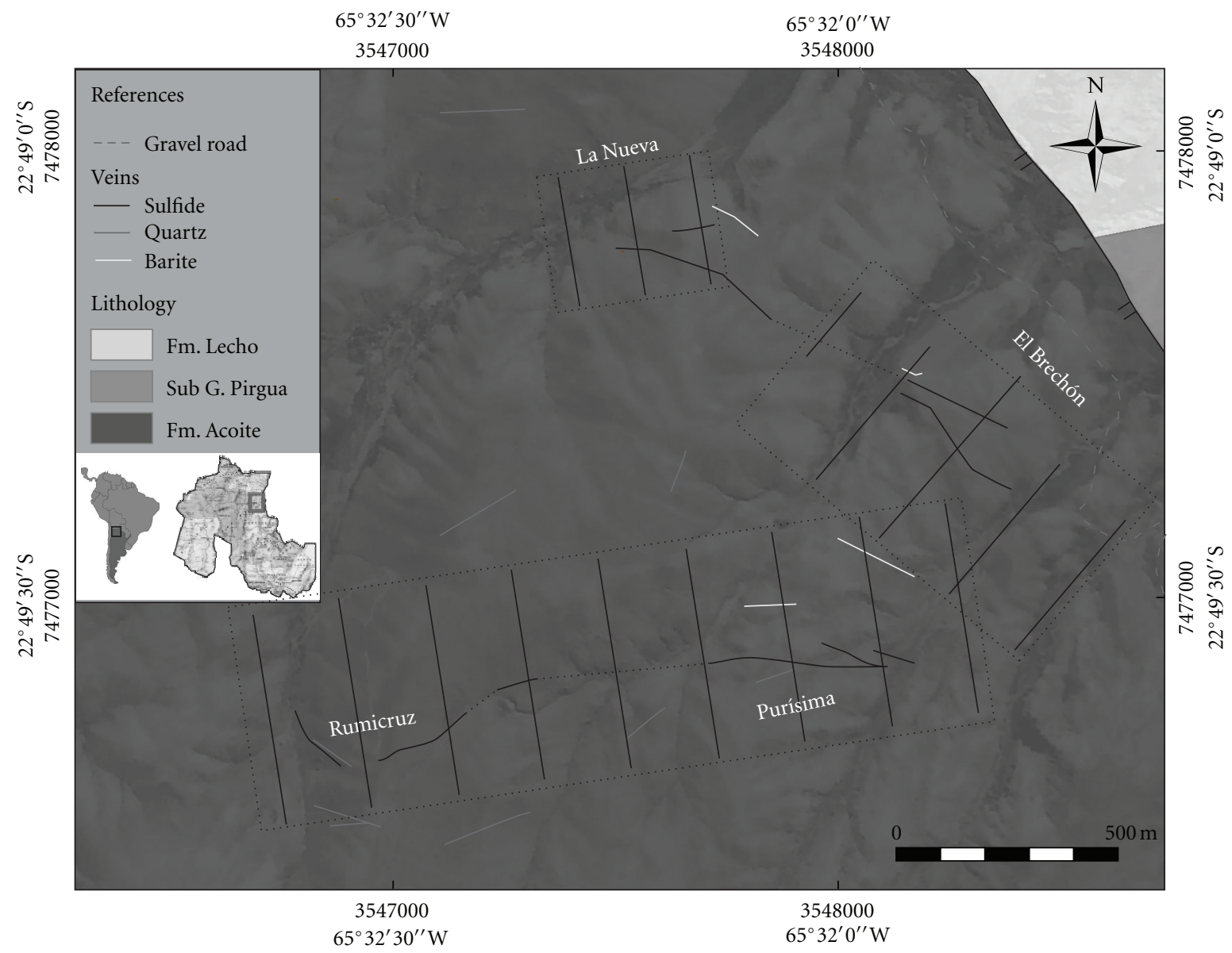

FIGURE 1: Simplified geologic map of Purísima-Rumicruz district and survey lines overlapped.

the mineralization are ductilly deformed by folding with a north-south axis, southwardly dipping. The fragile deformation is characterized by faults mainly with NW-SE and E-W orientations.

The veins present a breccia structure, with multiepisodic characteristics. According to the mineral association, there are two distinctive typologies: with quartz gangue and with calcite and baritine gangue. The former generally presents few metailiferous mineralizations, while the latter has sulfides and arsenides, and $\mathrm{Cu}-\mathrm{Pb}$ sulfur salts with trace contents of $\mathrm{Ni}, \mathrm{Co}, \mathrm{As}, \mathrm{Ag}$, and $\mathrm{U}$.

The vein system comprises some 3,500 m of outcropping structures. Veins run for short distances and present a rosarylike arrangement (Figure 1). The mineralization has been typified as five-element deposits $[7,8]$.

\section{Methods}

Geoelectric profiles were drafted for three zones labeled as La Nueva, Purísima, and El Brechón, according to the principal outcrops of metalliferous veins in the district. A lineal multielectrode arrangement was used to register data in a dipole-dipole fashion. The equipment used was an IPR-12 time domain IP/resistivity receiver with an
IPC-9/200 W power source, both manufactured by Scintrex. The equipment produced real-time automated readings, therefore enabling the operator to process as many samples as considered appropriate, within a variable number of cycles for each station.

Eight dipole potentials were read simultaneously, and resistivity and chargeability readings were logged in the equipment's memory. Additionally, the register of $\mathrm{K}$ constant readings for each position and the mean and standard deviation enable us to perform a reliability test on the induced polarization (IP) data stored.

The power source and the receptor are automatically synchronized, and the process is controlled by the first potential dipole. The source generates a continuous current, commuted in variable duration cycles. This allows to bypass spontaneous potential compensations, given that they are done statistically.

The apparent resistivity is then calculated by the formula

$$
\rho_{\mathrm{ap}}=K \frac{\Delta V}{I}
$$

where $K$ is the geometric constant of the device. Values are expressed in units of $\mathrm{ohm} \cdot \mathrm{m}$. 
TABLE 1: Absolute error for each iteration.

\begin{tabular}{lccccccccccc}
\hline \multirow{2}{*}{ Section } & \multirow{2}{*}{ Total number of data points } & \multicolumn{2}{c}{ Iteration 1 } & \multicolumn{2}{c}{ Iteration 2 } & \multicolumn{2}{c}{ Iteration 3 } & \multicolumn{2}{c}{ Iteration 4} & \multicolumn{2}{c}{ Iteration 5} \\
& & Res. & Char. & Res. & Char. & Res. & Char. & Res. & Char. & Res. & Char. \\
\hline No. 600 Purísima & 168 & 18.93 & 2.95 & 7.96 & 1.57 & 6.08 & 1.43 & 5.33 & 1.28 & 4.49 & 1.24 \\
No. 600 El Brechón & 136 & 21.55 & 5.65 & 10.41 & 3.40 & 9.15 & 3.11 & 6.88 & 3.00 & 4.58 & 2.96 \\
No. 200 La Nueva & 104 & 24.1 & 4.93 & 20.07 & 3.17 & 12.07 & 3.17 & 11.82 & 3.10 & 9.74 & 3.25 \\
\hline
\end{tabular}

Apparent chargeability is calculated on the time domain after the expression:

$$
M=\frac{V_{s} * 1000}{V_{p}}, \quad \text { where } V_{s}=\frac{\int_{t_{1}}^{t_{2}} V_{s} d t}{t_{r}},
$$

where $t_{1}$ is the initial time of measurements; $t_{2}$ is the final time of measurements; $t_{r}$ is the measurement interval $\left(t_{2}-\right.$ $\left.t_{1}\right) ; V_{p}$ is the tension during emission; $V_{s}$ is the tension measured during the integration period. Chargeability values are expressed in units of $\mathrm{mV} / \mathrm{V}$.

In the present study, electrodes were separated by $25 \mathrm{~m}$, and measurements for each station were taken for values ranging between $n=1$ and $n=8$ ( $n$ being the different depth levels for data recording). The duration of each cycle was $2 \mathrm{sec}$.

400-600 m long profiles were drafted with a separation of $200 \mathrm{~m}$ between profiles. La Nueva section was covered with three $400 \mathrm{~m}$ long profiles with NNW-SSE orientation. The exploratory objective was to search for the lateral continuity of a vein first observed with a small surface sounding, which evidenced a $50 \mathrm{~cm}$ wide structure, rich in calcosine. In order to map regional plots of resistivity, a $0-1,500 \mathrm{ohm} \cdot \mathrm{m}$ range with a $150 \mathrm{ohm} . \mathrm{m}$ interval was chosen. In the case of chargeability, fields were plotted with a $0-180 \mathrm{mV} / \mathrm{V}$ range and a $20 \mathrm{mV} / \mathrm{V}$ interval.

With the objective of identifying outcropping veins in the area and recognizing blind structures, the Purisima section was covered with nine $600 \mathrm{~m}$ long profiles. In order to map resistivity, the same intervals, as in the previous case, were used. In the case of chargeability, fields were plotted with a 0 $80 \mathrm{mV} / \mathrm{V}$ range and an $8 \mathrm{mV} / \mathrm{V}$ interval, due to the shallower bottom of this section.

Carrying out a prospective study of the continuity of $E l$ Brechón vein, the presence of polarizable minerals and the identification of associated blind structures, five $600-\mathrm{m}$ long profiles were drafted for El Brechón section. Having found lower resistivity values than in the other sections, a range of 0 to $>750 \mathrm{ohm} \cdot \mathrm{m}$ was chosen for mapping resistivity, plotting fields with $50 \mathrm{ohm} \cdot \mathrm{m}$ intervals. As in the previous section, chargeability fields were plotted with a $0-80 \mathrm{mV} / \mathrm{V}$ range and an $8 \mathrm{mV} / \mathrm{V}$ interval.

Geotomo's RES2DINV software was used in order to produce the 2D inversion model for resistivity and chargeability profiles [9-11]. The 2D model consists of a number of rectangular blocks with an arrangement linked to the distribution of data points in the pseudosections. The program uses a modeling subroutine in order to compute apparent resistivity values forward, a nonlineal minimum squares optimization technique for the inversion routine
$[12,13]$. The aim of the program is to produce an apparent resistivity pseudosection that adjusts to real measurements, determining resistivity for the rectangular blocks. The optimization method basically reduces the difference between the calculated apparent resistivity values and those measured, adjusting the resistivity of the model's blocks (Figures 2, 3 , and 4). A measure of this difference is determined by the quadratic mean error (RMS). However, with the lowest RMS possible, the model can sometimes show great artifact variations in resistivity values, and it may not always be the most adequate model from a geologic perspective. In general, the most cautious approach is to choose an iteration model in which the RMS does not change significantly (Table 1).

The same method used in mining prospection for determining geochemical anomalies [14] was used to obtain normal (background) chargeability values, given that chargeability values present a distribution that fits well into a lognormal model (after Kolmogorov-Smirnov's goodness of fit test, $P<0.01$ in all cases). A background upper limit or threshold was determined as the mean $+2 \mathrm{SD}$; chargeability values higher than the threshold were considered anomalous.

\section{Results}

Results from the inversion of geoelectric data and true resistivities and chargeabilities indicate that rocks of the Acoite formation present resistivity values characteristic of those of sedimentary rocks, with a mean value of $319 \mathrm{ohm} \cdot \mathrm{m}$. Induced polarization values obtained from the inversion model are generally very high, with some values $>150 \mathrm{mV} / \mathrm{V}$ and a mean value for the three sections of $23 \mathrm{mV} / \mathrm{V}$. The analysis of chargeability data indicates that there were highly significant differences among the mean values of each section (ANOVA, $\left.F_{(2 ; 4688)}=287.32 ; P=0.00\right)$ (Figure 5). Table 2 lists descriptive statistics for resistivity and chargeability for each zone.

4.1. La Nueva Section. Figure 6 shows LN200 resistivity and chargeability profiles for the section. In the first case, the distribution of resistivities is irregular. In general, the low resistivity zone is placed on the southern margin of the vein; to the south there is a homogeneous zone of moderate resistivities, whereas to the north the pattern is more heterogeneous, mainly presenting low-resistivities and interspersed small shallow zones of high resistivities. The chargeability profile shows a large anomalous zone located $\sim 50 \mathrm{~m}$ south of the vein and separated by a very low chargeability band which coincides with the low resistivity band. To the north of the vein, chargeability is comparatively moderate to low. 

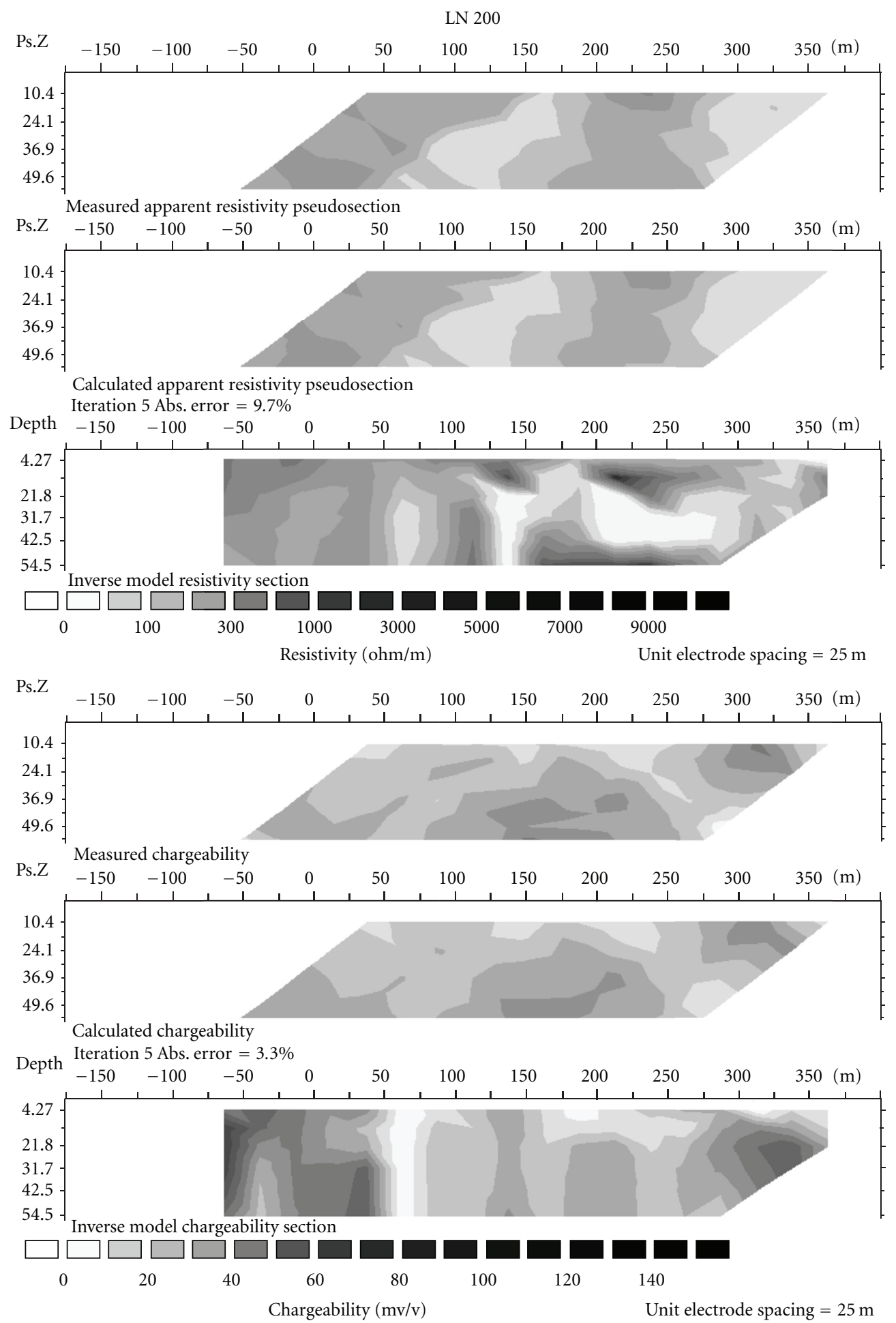

FIGURE 2: Measured and calculated apparent pseudosections and inverse models sections of resistivity and chargeability for no. $200 \mathrm{La}$ Nueva section.

4.2. Purísima Section. As in the previous case, two low chargeability zones located approximately on the main valley axis separate two sections with different resistivities (i.e., low resistivity in the south and high in the north). The deep zones of the veins comprised in profile no. 600 are spatially associated to one of the low-resistivity zones located southward of the valley axis (Figure 7). With respect to chargeability, the anomalous zone is located some $50 \mathrm{~m}$ deep in the area of veins. In general, chargeabilities southward of the valley axis are higher than those to the north. 


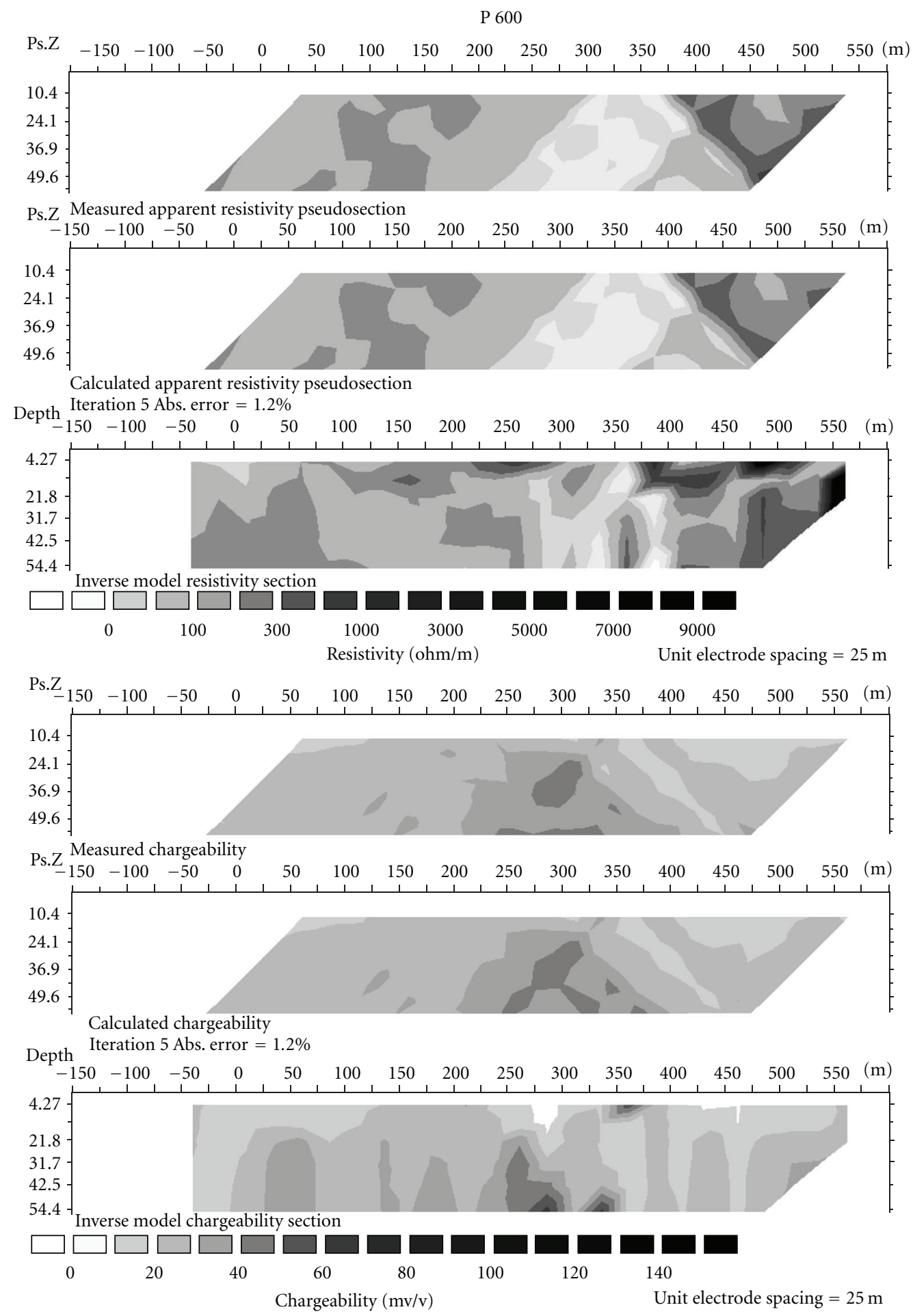

FIGURE 3: Measured and calculated apparent pseudosections and inverse models sections of resistivity and chargeability for no. 600 Purísima section.

4.3. El Brechón Section. Figure 8 shows profile no. 600 for the section. In this section, the vein coincides spatially with a tabular, very low resistivity band, which is $<50 \mathrm{ohm} \cdot \mathrm{m}$. Although the resistivity distribution on the rest of the profile is heterogeneous, the NE section is generally more resistive than the SW section.

Chargeabilities are also heterogeneously distributed; the more developed anomalous zone is clearly unrelated to 


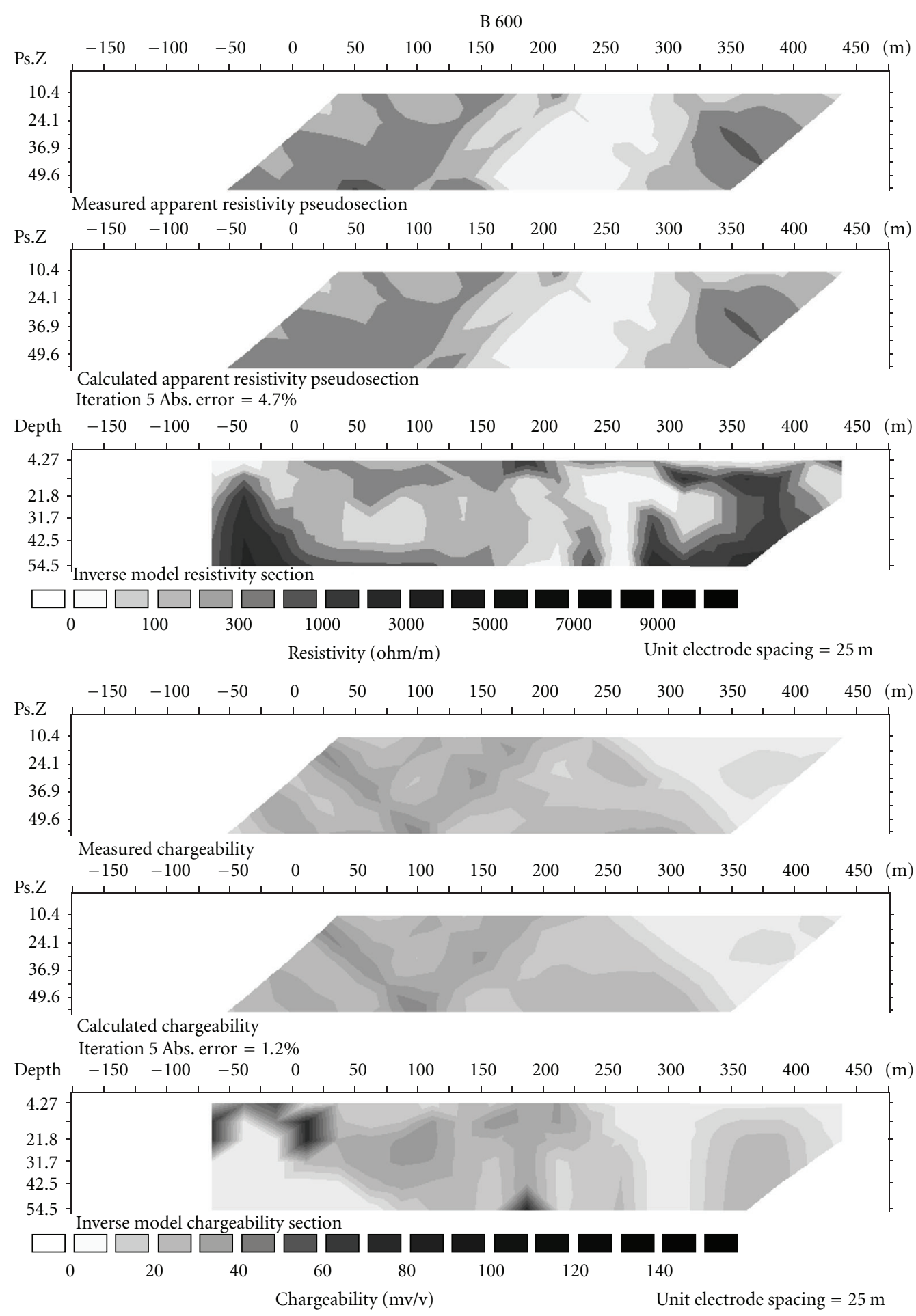

FIGURE 4: Measured and calculated apparent pseudosections and inverse models sections of resistivity and chargeability for no. 600 Brechón section.

the section's vein. Below $50 \mathrm{~m}$, a small anomaly coincides spatially with the vein.

\section{Interpretation and Discussion}

5.1. Resistivity. Mean resistivity values obtained using the inversion model for the three sections studied are characteristic of sedimentary rocks, compatible with shales limolitas [15, 16]. There was, however, great variability between very lowresistivity zones, from a few ohm.m to very high values $>20,000 \mathrm{ohm} \cdot \mathrm{m}$.

Resistivity studies can provide useful information for the prospection of mineralized structures, such as those identified in the Purísima-Rumicruz district, where the 


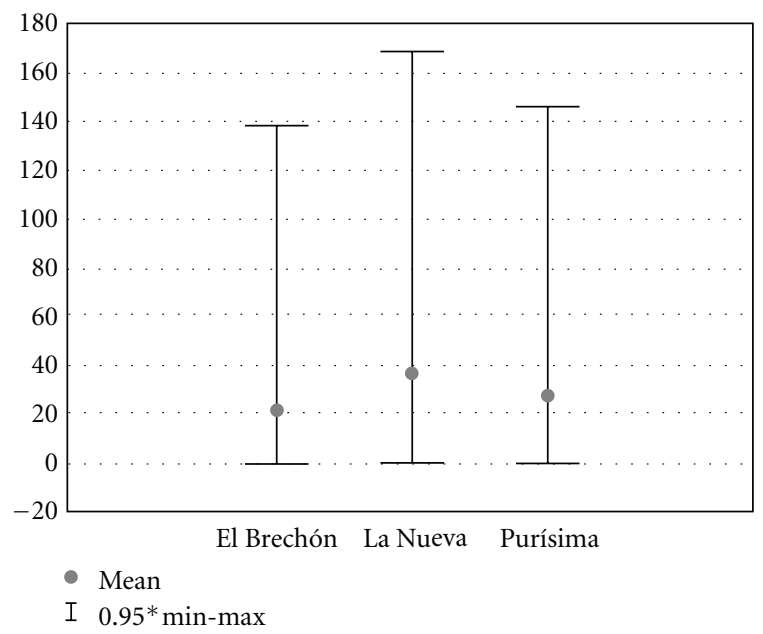

FIGURE 5: Box and whisker plot for chargeability (induced polarization, IP).

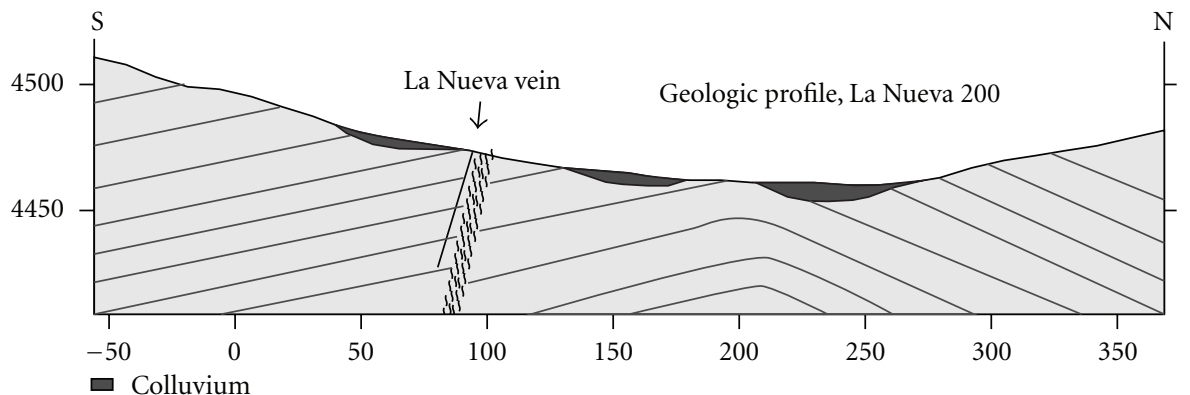

$\square$ Acoite formation
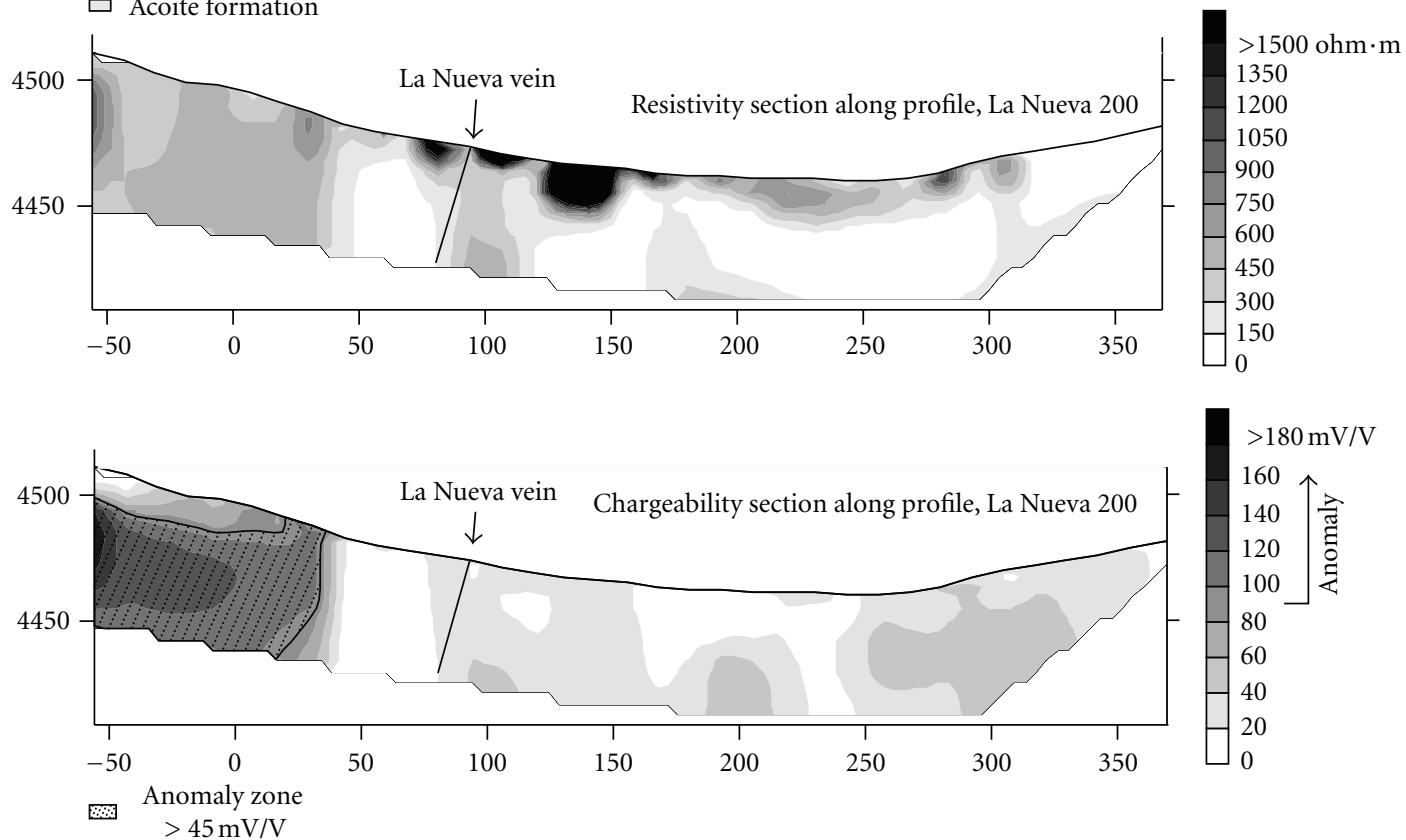

FiguRE 6: Geological, resistivity, and chargeability profile no. 200 for La Nueva section. The vein studied is spatially associated with lowresistivity and -chargeability areas. A large area presenting anomalous chargeability is located southward of the vein. 

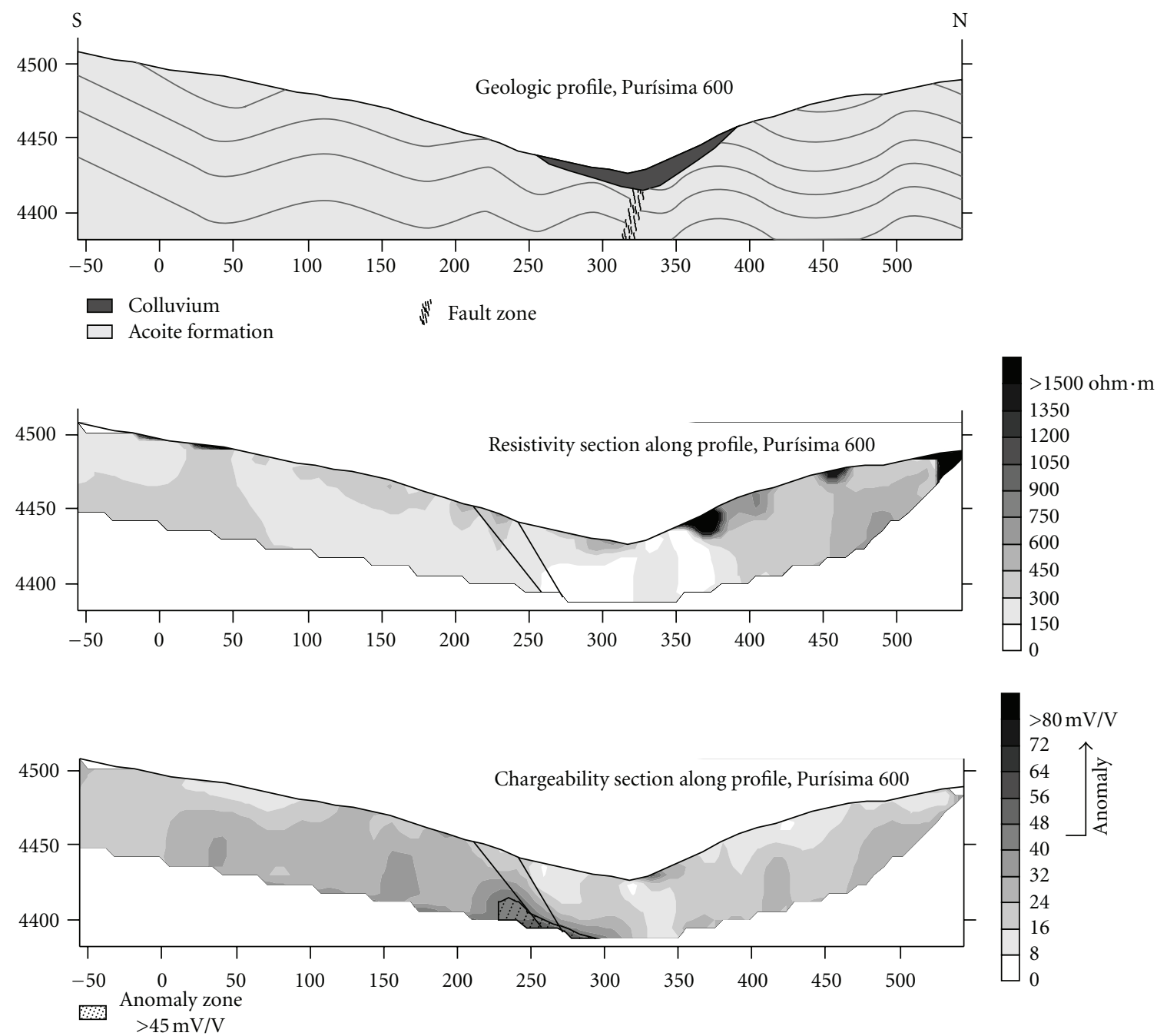

FIGURE 7: Geological, resistivity, and chargeability profile no. 600 for Purísima section. The veins studied are spatially associated with a low-resistivity area, coincident with the valley's main axis. An anomalous chargeability area coincides with the veins at $50 \mathrm{~m}$ depths.

TABLE 2: Resistivity $(\mathrm{ohm} \cdot \mathrm{m})$ and chargeability values $(\mathrm{mV} / \mathrm{V})$. Chargeability anomalies are identified as the mean $+2 \mathrm{SD}$.

\begin{tabular}{lcccccccc}
\hline & \multicolumn{2}{c}{ La Nueva $(n:$ 984) } & \multicolumn{2}{c}{ Purísima $(n:$ 4208) } & \multicolumn{2}{c}{ El Brechón $(n: 1862)$} & \multicolumn{2}{c}{ All $(n: 7054)$} \\
& Res & IP & Res & IP & Res & IP & Res \\
\hline Mean & 259 & 37 & 384 & 21 & 206 & 21 & 319 \\
Median & 157 & 32 & 254 & 19 & 129 & 16 & 192 \\
SD & 454 & 26 & 781 & 12 & 427 & 19 & 669 \\
Max. & 5,813 & 177 & 20,325 & 154 & 8,828 & 145 & 20,325 \\
Min. & 14.4 & 0.11 & 13 & 0.02 & 5.82 & 0.03 & 6 \\
IP. Anom. & & $>89$ & & $>45$ & & $>59$ & 0 \\
\hline
\end{tabular}

veins are located in multiepisodic faults. On the one hand, fractured bands can generate low resistivity zones due to a strong increment in the porosity from rock fractures $[5,17-$ 20]. On the other hand, this result, in rocks with different resistivities placed adjacently at each side of the fault [20].

In the three sections of the district comprised in this study, low resistivity zones were recognized, which might be interpreted as the result of an increased effective porosity, itself the product of faults. The tabular structure of some of these zones, and their spatial association with mineralized structures (i.e., La Nueva and El Brechón), indicates that they might as well be filled-in fault zones. In the case of Purisima section, even though the low resistivity zone coincident with the deep zone of veins on profile no. 600 does not have tabular structures, its alignment with the valley's axis indicates that it might be associated with a faulty zone. 

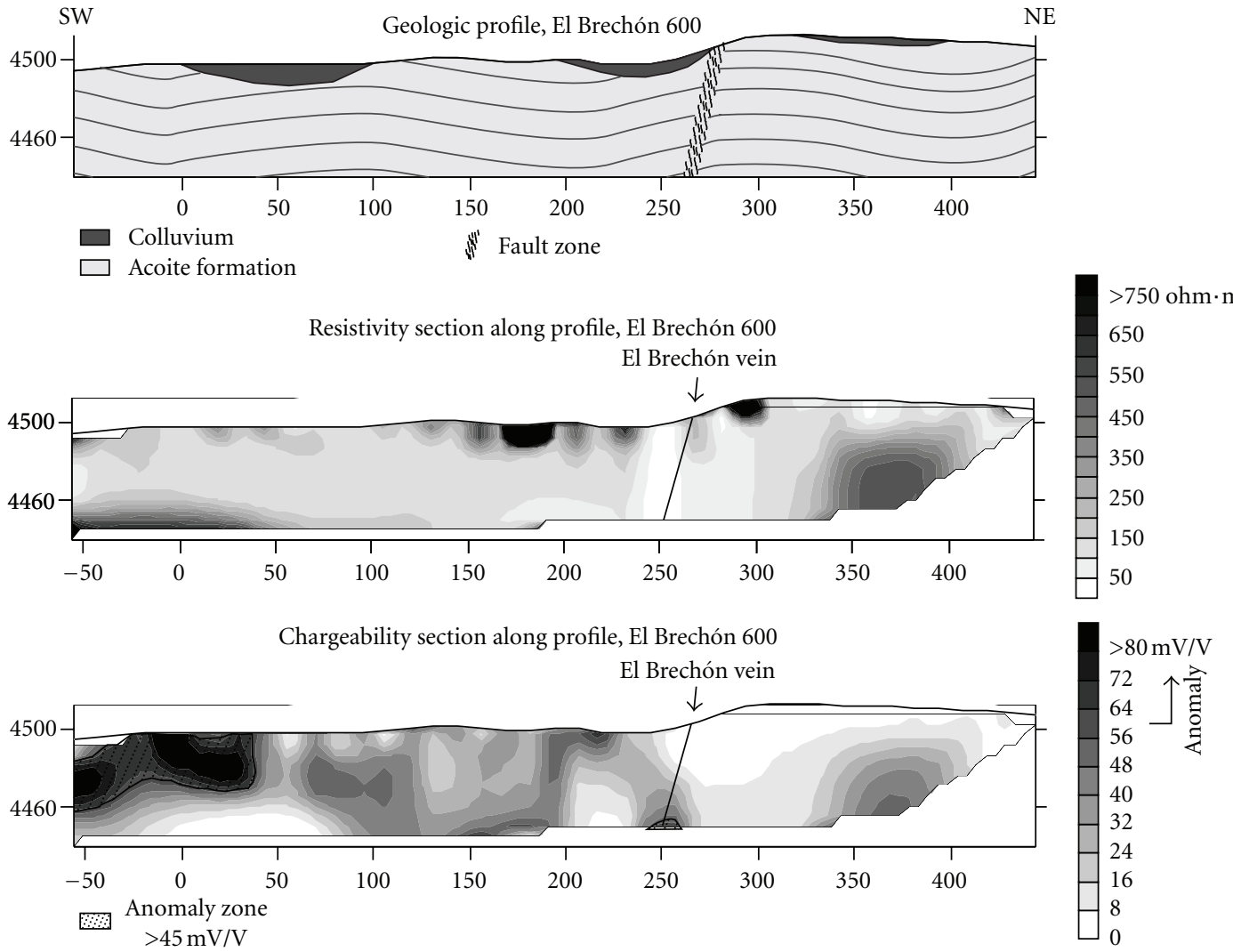

FIGURE 8: Geological, resistivity, and chargeability profile no. 600 for El Brechón section. The vein is spatially associated with a low-resistivity tabular area. An extensive area presenting anomalous chargeability is noted on the SW section of the profile and a smaller one in the deep zone (below $\sim 50 \mathrm{~m}$ ) of the vein.

Resistivity values in these zones $(0-150 \mathrm{ohm} \cdot \mathrm{m})$ are similar to those recorded by Suzuki et al. [21] in Paleozoic shales with a high degree of fragmentation due to faults. These authors also found that resistivity declines gradually as a function of the intensity of cataclasis. The mean resistivity value in shales is $450 \mathrm{ohm} . \mathrm{m}$, similar to that of low-degree metamorphic rocks of Acoite formation.

In La Nueva and El Brechón sections, low resistivity bands associated with the veins clearly separate zones with different geoelectric characteristics. An interpretation of this is that the faults that harbor the current mineralization brought together different lithologic types in the same formation.

5.2. Chargeability. The chargeability values recorded in this study are not frequent in sedimentary rocks. Some chargeability values were as high as those of porphyry copper and gold [22]. Even though the presence of graphite, clay minerals, and the mineralogical composition of some basic rocks can produce high chargeability [23], in the case of Acoite formation this might be due to the relatively high abundances of disseminated pyrite (probably of diagenetic origin). The majority of pyrite grains in Acoite have framboidal texture, characteristic of precipitations under abiotic conditions in an euxinic environment during diagenesis [24]. Therefore, they are genetically unrelated to the polymetallic mineralization present elsewhere in the mining district. The mean grain size of framboidal pyrite at Acoite formation is in the order of $10 \mu \mathrm{m}$, which favors an increment in induced polarization. Grain size is an important variable in IP records; a fine granulometry of polarizing minerals translates into greater surface and, accordingly, into an increase in chargeability (with constant volume) [25].

These characteristics of the host rock explain the high background chargeability values registered, which are not necessarily related to metallic mineralization in the district. Our discriminating analysis by area indicates that there are considerable differences in chargeability.

Both in La Nueva and El Brechón sections, the larger volume and anomalous chargeability zones $(>90 \mathrm{mV} / \mathrm{V}$ and $>59 \mathrm{mV} / \mathrm{V}$, resp.) are spatially unrelated to the zones where the veins outcrop. The extent of their developments might point to an association with disseminating diagenetic pyrite in the host rock, rather than being associated with a hydrothermal polymetallic mineralization. On the other hand, in La Nueva section, the presence of outcroppings stained by iron oxides on top of the anomaly (surely a byproduct of meteoric altering of pyrite) reinforces the idea that zones with anomalous chargeability are linked to a marked pyritization of the host rock.

On Purísima and El Brechón sections, below 40 and $50 \mathrm{~m}$, respectively, small chargeability anomalies appear spatially associated to veins, which can be attributed to an 
epigenetic hydrothermal mineralization within a pyritized host rock. Pittard and Bourne [26] reported similar results for Centenary gold deposit (Australia), in reference to increased IP values given by the minerals coming from the host rock, unrelated to economic mineralization. In this case, chargeability is due to the pyrite associated with gold, sharing a common hydrothermal origin, and to magnetite, a hypogenic mineral in doleritic host rocks.

\section{Conclusions}

The geoelectric exploration of the Purísima-Rumicruz district revealed a marked relationship between low resistivity bands and mineralizations located in faulty zones. The fracture plane of the rock enabled fluid circulation and mineral precipitation, while the reactivation of the faults produced multiepisodic breachy structures, which characterize the district. As a consequence of fractures, the resulting increased porosity and permeability would decrease resistivity to values below $150 \mathrm{ohm} \cdot \mathrm{m}$ in bands that stand out from the host rocks. Moreover, these faulty zones become evident by linking together lithologic varieties of different geoelectric properties.

In general, the high IP values registered seem to be the product of a stronger diagenetic pyritization of the host rock rather than an epigenetic mineralization. Anomalous zones comprise large rock volumes spatially unrelated to outcropping veins and the faulty zones that acted as mineralization traps. However, small zones with anomalous chargeability located below depths $\sim 50 \mathrm{~m}$ over veins from Purísima and El Brechón sections constitute good exploratory targets.

\section{References}

[1] H. O. Seigel, "Mathematical formulation and type curves for induced polarization," Geophysics, vol. 24, no. 3, pp. 547-565, 1959.

[2] J. S. Sumner, Principles of Induced Polarization for Geophysical Exploration, Elsevier, Amsterdam, The Netherlands, 1976.

[3] J. B. Fink, E. O. McAlister, B. K. Sternberg, W. G. Wieduwilt, and S. H. Ward, Eds., Induced Polarization, Applications and Case Histories, Investigations in Geophysics, Society of Exploration Geophysicists, 1990.

[4] B. Khesin, V. Alexeyev, and L. Eppelbaum, "Rapid methods for interpretation of induced polarization anomalies," Journal of Applied Geophysics, vol. 37, no. 2, pp. 117-130, 1997.

[5] S. A. Sultan, S. A. Mansour, F. M. Santos, and A. S. Helaly, "Geophysical exploration for gold and associated minerals, case study: Wadi El Beida area, South Eastern Desert, Egypt," Journal of Geophysics and Engineering, vol. 6, no. 4, pp. 345356, 2009.

[6] D. M. Guido, S. M. Jovic, H. Echeveste, M. O. Tessone, L. Ramayo Cortes, and I. B. Schalamuk, "Polymetallic ore-shoots discovery and modelization with geoelectric surveys. Pingüino project, Deseado Massif," Revista de la Asociacion Geologica Argentina, vol. 64, no. 3, pp. 383-390, 2009.

[7] C. S. Lurgo Mayón, "Depósitos polimetálicos ricos en níquel, cobalto y arsénico de la Cordillera Oriental, Jujuy y Salta," in Recursos Minerales de la República Argentina, E. O. Zappettini, Ed., vol. 35, pp. 999-1004, Instituto de Geología y Recursos Minerales SEGEMAR, Anales, Buenos Aires, Argentina, 1999.
[8] L. López, H. Echeveste, and I. B. Schalamuk, "Nuevos aportes en el distrito minero Purisima Rumicruz, provincia de Jujuy," in Actas del 17th Congreso Geologico Argentino, vol. 2, pp. 607608, 2008.

[9] M. H. Loke, "Tutorial: 2-D and 3-D electrical imaging surveys," Geotomo Software, 1996.

[10] M. H. Loke and R. D. Barker, "Rapid least-squares inversion of apparent resistivity pseudosections by a quasi-Newton method," Geophysical Prospecting, vol. 44, no. 1, pp. 131-152, 1996.

[11] M. H. Loke, "Rapid 2-D resistivity and IP inversion using the least-squares method," Geoelectrical Imaging 2-D and 3-D, Geotomo Software, 2001.

[12] C. Degroot-Hedlin and S. Constable, "Occam's inversion to generate smooth, two-dimensional models from magnetotelluric data," Geophysics, vol. 55, no. 12, pp. 1613-1624, 1990.

[13] Y. Sasaki, "Resolution of resistivity tomography inferred from numerical simulation," Geophysical Prospecting, vol. 40, no. 4, pp. 453-463, 1992.

[14] C. Lepeltier, "A simplified statistical treatment of geochemical data by graphical representation," Economic Geology, vol. 64, no. 5, pp. 538-550, 1969.

[15] E. Orellana, Prospección geoeléctrica en corriente continua, Paraninfo, Madrid, Spain, 1982, Segunda edición corregida y ampliada.

[16] A. López Hidalgo, M. H. Loke, G. O. Fanton, Rubí, and E. C, "Técnicas prácticas para investigación de resistividad en dos y tres dimensiones (Tomografía Eléctrica 2D y 3D),” 2011, http://www.geoelectrical.com/Articulo.pdf.

[17] S. I. Giano, V. Lapenna, S. Piscitelli, and M. Schiattarella, "Electrical imaging and self-potential surveys to study the geological setting of the Quaternary slope deposits in the Agri high valley (Southern Italy)," Annali di Geofisica, vol. 43, no. 2, pp. 409-419, 2000.

[18] D. Demanet, F. Renardy, K. Vanneste, D. Jongmans, T. Camelbeeck, and M. Meghraoui, "The use of geophysical prospecting for imaging active faults in the Roer Graben, Belgium," Geophysics, vol. 66, no. 1, pp. 78-89, 2001.

[19] A. Colella, V. Lapenna, and E. Rizzo, "High-resolution imaging of the High Agri Valley Basin (Southern Italy) with electrical resistivity tomography," Tectonophysics, vol. 386, no. 1-2, pp. 29-40, 2004.

[20] S. Y. Fazzito, A. E. Rapalini, J. M. Cortés, and C. M. Terrizzano, "Characterization of Quaternary faults by electric resistivity tomography in the Andean Precordillera of Western Argentina," Journal of South American Earth Sciences, vol. 28, no. 3, pp. 217-228, 2009.

[21] K. Suzuki, S. Toda, K. Kusunoki, Y. Fujimitsu, T. Mogi, and A. Jomori, "Case studies of electrical and electromagnetic methods applied to mapping active faults beneath the thick Quaternary," Engineering Geology, vol. 56, no. 1-2, pp. 29-45, 2000.

[22] R. M. S. White, S. Collins, R. Denne, R. Hee, and P. Brown, "A new survey design for 3D IP inversion modelling at Copper Hill," Exploration Geophysics, vol. 32, no. 4, pp. 152-155, 2001.

[23] R. B. Evans and A. J. Burley, Variable Frequency Induced Polarization Surveys in Western Swaziland: April to June 1968: Institite of Geological Sciences, Overseas Geological Surveys, Geophysical Division, Report, Issue 41, Overseas Geological Surveys (Great Britain), London, UK, 1969.

[24] I. Butler, D. Rickard, and S. Grimes, "Framboidal Pyrite: self Organization in the Fe-S System," Goldschmidt, Journal of Conference Abstracts, vol. 5, pp. 276-277, 2000. 
[25] J. Wong, "An electrochemical model of the induced-polarization phenomenon in disseminated sulfide ores," Geophysics, vol. 44, no. 7, pp. 1245-1265, 1979.

[26] K. Pittard and B. Bourne, "The contribution of magnetite to the induced polarization response of the Centenary orebody," Exploration Geophysics, vol. 38, no. 3, pp. 200-207, 2007. 

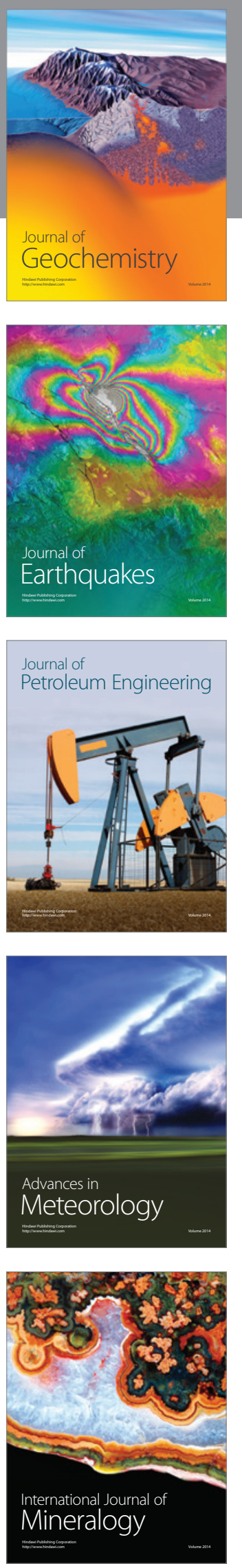
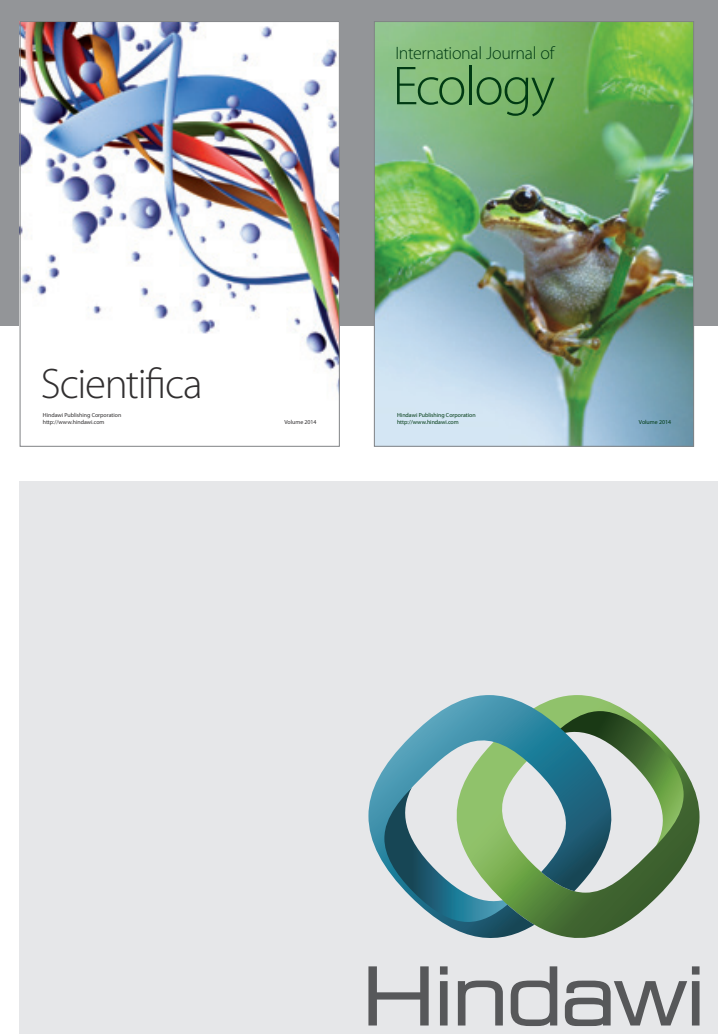

Submit your manuscripts at http://www.hindawi.com
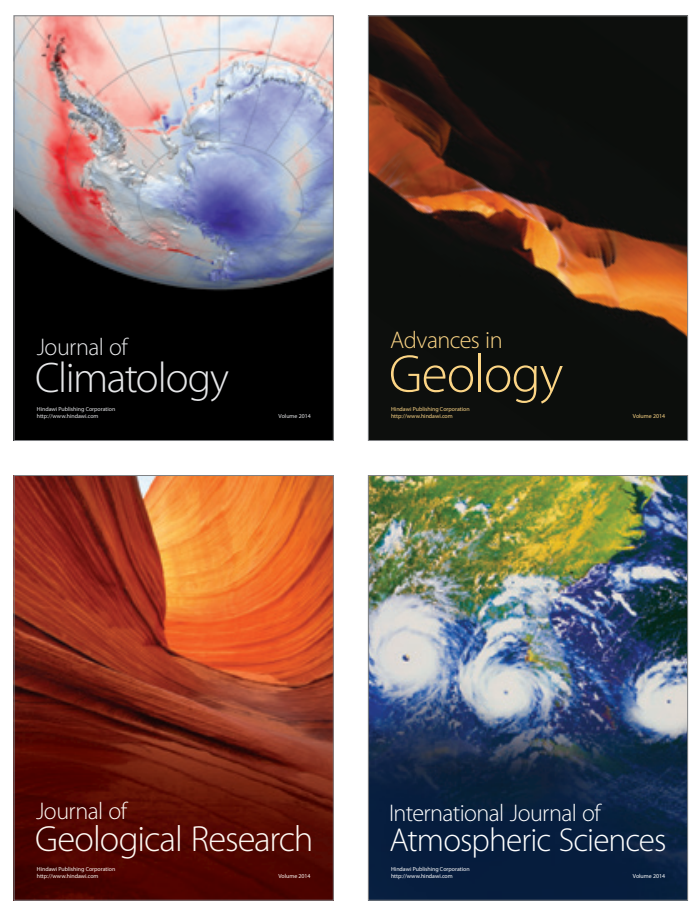
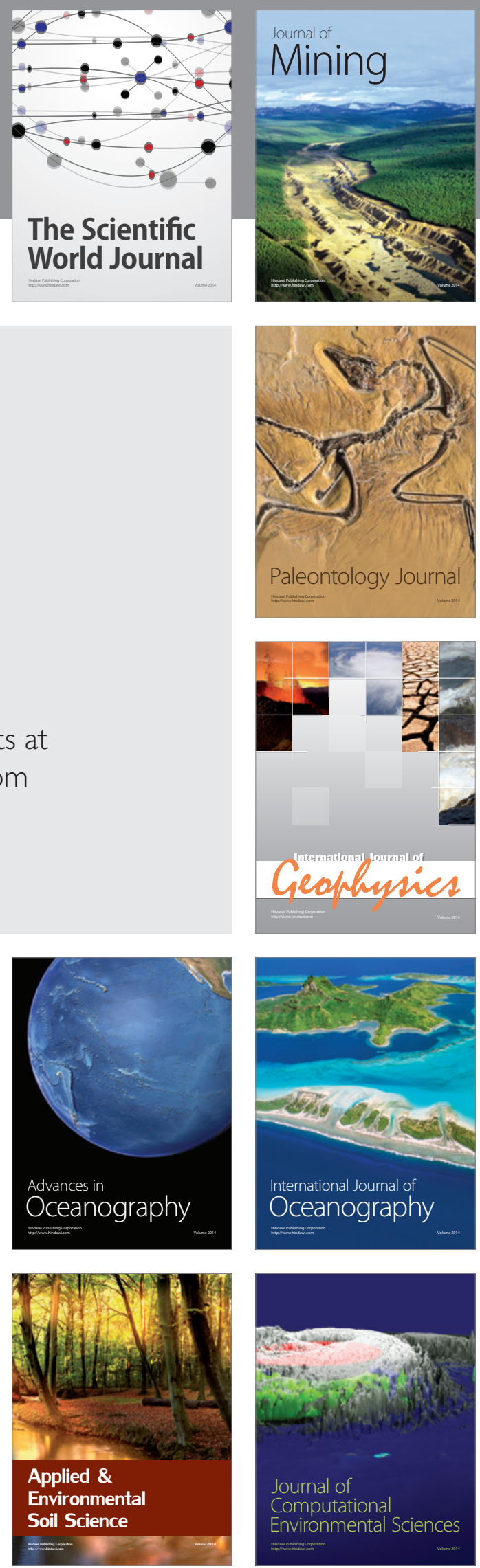